\title{
UNCLOS 1982 DAN ICAO 1947 DALAM PENGATURAN RUANG UDARA
}

Oleh :

DR. A. Dirwan. M.Sc

\begin{abstract}
Abstrak:
Indonesia sebagai salah satu negara kepulauan, telah meratifikasi UNCLOS/ United Nations Convention On The Law Of The Sea dengan UU Nomor 17 tahun 1985 sebagai kelanjutan perwujudan dari konsep Doktrin Wawasan Nusantara yang merupakan satu kesatuan terhadap tanah, daratan dan perairan. Namun dalam hal ini masih ada masalah yang timbul di antaranya adalah masalah alur laut kepulauan yang diatur oleh IMO/ International Maritime Organization dan masalah yurisdiksi dari International Tribunal yang menurutnya overlapping dengan yurisdiksi International Civil Aviation Organization (ICAO)Council. Hal ini semata-mata berkaitan dengan "Penafsiran hak lintas Udara".
\end{abstract}

\section{PENDAHULUAN}

Pengakuan internasional terhadap prinsipprinsip Negara kepulauan yang sekian lama diperjuangkan oleh Bangsa Indonesia, telah menjadi kenyataan dengan disepakatinya hukum laut internasional "United Nations Convention On The Law Of The Sea" (UNCLOS 1982), yang ditandatangani oleh 117 negara pada tanggal 10 Desember 1982.

Negara kepulauan yang dijelaskan dalam pasal 46 UNCLOS 1982, berarti suatu negara yang seluruhnya terdiri dari satu atau lebih kepulauan dan dapat mencakup beberapa pulau. "Kepulauan" berarti suatu gugusan pulau, termasuk bagian pulau, perairan diantaranya dan wujud alamiah yang hubungan satu sama lain demikian eratnya, sehingga pulau-pulau, perairan dan wujud alamiah tersebut, merupakan suatu kesatuan geografi, ekonomi dan politik yang hakiki. Indonesia sebagai salah satu negara kepulauan, telah meratifikasi UNCLOS tersebut dengan UU Nomor 17 tahun 1985 sebagai kelanjutan perwujudan dari konsep Doktrin Wawasan Nusantara yang merupakan satu kesatuan terhadap tanah, daratan dan perairan. 
Di sisi lain ICAO sebagai suatu organisasi penerbangan sipil internasional mengkuatirkan terjadi tumpang tindih dalam aplikasi antara ketentuan ICAO dan UNCLOS 1982, khusus dalam pasal 53 ayat (2) UNCLOS 1982, yang disebutkan "semua kapal dan pesawat udara menikmati hak lintas Alur Laut Kepulauan dalam alur laut dan rute penerbangan". Pada hal rute-rute penerbangan telah diatur tersendiri oleh ICAO.

Salah satu dokumen ICAO yang dimuat dalam laporan Legal Committee pada sidang Council ICAO dengan nomor Doc. 9693 LC/190 tertanggal 2 Juni 1997 menyatakan bahwa masalah yang timbul dengan berlakunya UNCLOS 82, di antaranya adalah masalah alur laut kepulauan yang diatur oleh IMO dan masalah yurisdiksi dari International Tribunal yang menurutnya overlapping dengan yurisdiksi ICAO Council.

Penafsiran hak lintas tersebut diatas, khususnya untuk pesawat militer pada ketentuan "penerbangan secara normal semata-mata untuk melakukan transit yang terus menerus, langsung dan secepat mungkin" telah ditafsirkan berbeda-beda oleh setiap negara.

Seperti pada Kasus Bawean ${ }^{1}$ Amerika menyatakan bahwa dengan menerbangkan

"Kasus Bawean" terjadi pada tanggal 3 Juli 2003. Ada 5 Pesawat F-18 yang terbang dari USS Carl Vinson yang berlayar pada alur laut kepulauan Indonesia berada disekitar $P$. Bawean dalam rangka melaksanakan pengamanan kapal Induk, pesawat tersebut terbang dengan melaksanakan berbagai manuver. Karena pesawat tersebut tidak memiliki ijin dan tidak melakukan komunikasi sebagaimana yang diatur dalam ketentuan penerbangan, 2 (dua) pesawat F-16 TNI AU terbang dari Lanud Iswahyudi Madiun untuk melaksanakan identifikasi. Dua Flight pesawat tempur saling berhadapan tanpa komunikasi yang akhirnya hampir terjadi pertempuran, untungnya para pilot tersebut melaksanakan prosedur identifikasi secara benar dan pesawatnya dari kapal induk adalah suatu keadaan "normal semata-mata" sesuai ketentuan normal untuk kepentingan pengawasan kapal induknya. Dilain pihak beberapa negara kepulauan seperti Indonesia mempunyai penafsiran sendiri, dan menyatakan apa yang dilakukan oleh pesawat-pesawat Amerika adalah pelanggaran baik terhadap UNCLOS 1982 maupun terhadap Hukum Udara.

Perbedaan penafsiran yang timbul, karena tidak secara jelas dan tegas, tentang bagaimana penggunaan rute udara diatas alur laut kepulauan baik untuk pesawat negara atau sipil. Untuk itu perlu suatu pengkajian penselarasan pasal-pasal UNCLOS 82 , tentang rute udara diatas alur laut kepulauan berdasarkan hukum udara yang berlaku. Dengan demikian dalam penggunaan rute udara diatas alur laut kepulauan tetap berdasarkan prinsip prinsip keselamatan penerbangan.

\section{DASAR PEMIKIRAN}

Ruang udara nasional suatu negara, dalam penggunaannya baik untuk mendukung kepentingan nasional ataupun menampung aspirasi internasional termasuk untuk keamanan dan keselamatan penerbangan diatur oleh hukum internasional dan diratifikasi menjadi hukum nasional oleh negara bersangkutan. Pengaturan ruang udara secara internasional ditetapkan berdasarkan Konvensi Chicago 1944.

Untuk hukum laut diatur melalui UNCLOS 1982 yang didalamnya juga mengatur ruang udara, khususnya bagi pesawat udara asing yang melintas diatas Alur laut kepulauan yang ditetapkan. Beberapa pendekatan yang digunakan :

pesawat F-18 kembali landing di Kapal Induk tersebut dengan aman. 


\section{a. Convention on International Civil Aviation of 1944.}

Konvensi ini yang selanjutnya disebut sebagai Konvensi Chicago 1944, diprakarsai oleh Amerika Serikat pada tanggal 11 September 1944. Dalam pertemuan tersebut Amerika Serikat mengajukan proposal tentang ketentuan-ketentuan untuk navigasi udara internasional dan kalau memungkinkan dapat menghasilkan prinsip-prinsip hukum udara yang dapat menjadi sebuah Konvensi. ${ }^{2}$ Dibandingkan dengan Konvensi Paris 1919, menurut Sand, Pratt dan Lyon dalam bukunya "An Historical Survey of The Law of Flight" yang diterbitkan tahun 1961 dan dikutip oleh E. Suherman bahwa kedaulatan negara pada saat itu berorientasi pada aspek keamanan negara sedangkan Konvensi Chicago pada aspek ekonomi bagi industri angkutan udara nasional. ${ }^{3}$

Namun kemudian, Konvensi ini tidak saja mengatur tentang landasan hukum bagi pelaksanaan penerbangan sipil internasional, ${ }^{4}$ tapi juga beberapa pasal yang berhubungan dengan pelaksanaan kedaulatan dan penggunaan pesawat negara. Beberapa pasal yang dapat dijadikan bahan diskusi :

\section{1) Pasal 1.}

Konvensi mengakui adanya hak berdaulat di wilayah udara teritorial suatu negara. ("The contracting States

\footnotetext{
2 Wenceslas J. Wagner, Internasional Air Transportation As Affected By State Sovereignty, (Bruylant.Bruxelles: Establissements Emile Bruylant 67, rue de la regence, 1970) halaman 90-91.

3 E. Suherman, Hukum Udara Indonesia \&

Internasional, (Bandung: Penerbit Alumni/1983), halaman 168.

4 Convention on Internasional Civil Aviation of 1944, Pasal 3 ayat (1)
}

recognize that every State has complete and exclusive sovereignty over the airspace above its territory ${ }^{5 ")}$.

\section{2) Pasal 3 Huruf (c).}

Sebagai implementasi pasal 1 tersebut di atas, setiap pesawat negara harus mempunyai izin khusus dari suatu negara, baik sebagai tujuan atau hanya sekedar lewat di atas wilayah udara negara tersebut.

3) Pasal 3 Huruf (d).

Untuk penerbangan dengan menggunakan pesawat negara, dalam Konvensi ini hanya memberikan tanggung jawab kepada negara bahwa untuk sejauh mungkin dalam melakukan penerbangannya memperhatikan keselamatan penerbangan sipil.

4) Annex 2, Rules Of the Air.

Dalam bagian 2 Ayat (1.1), ditegaskan bahwa ketentuan mengenai hukum udara harus tetap berlaku bagi setiap pesawat diwilayah udara negara manapun mereka terbang dan tidak boleh ada konflik dengan ketentuan dari negara yang bersangkutan. Di samping itu sebelum penerbangan informasi mengenai maksud penerbangan harus diinformasikan ke unit pengatur lalu lintas udara suatu negara, dalam bentuk Flight Plan.

\section{5). Annex 11, Air Traffic Services.}

Dalam ketentuan ini dijelaskan sasaran dari air traffic services atau

Pengertian territory dalam Konvensi ini dijelaskan dalam Pasal 2 "For the purpose of this Convention the territory of a state shall be deemed to be the land areas and territorial waters adjacent thereto under the sovereignty, suzerainty, protection or mandate of such State" 
pelayanan lalu lintas udara yaitu mencegah tubrukan antar pesawat, dan antara pesawat di area pergerakan dengan benda lain di darat, memperlancar dan mempertahankan keteraturan arus lalu lintas udara, memberikan saran dan informasi yang berguna untuk keselamatan dan efisiensi penerbangan, memberikan informasi bila suatu pesawat harus dilakukan pencarian dan pertolongan, serta membantu badan Search and Rescue (SAR) jika diperlukan.

\section{b. UNCLOS 1982.}

Konvensi ini menjadi dasar hukum di wilayah laut yurisdiksi suatu negara, antara lain wilayah kedaulatan yang mencakup wilayah teritorial, perairan pedalaman dan perairan kepulauan, zona tambahan, zona ekonomi eksklusif dan landas kontinen. Atas wilayah tersebut negara mempunyai hak-hak dan kewajiban tertentu, di samping negara lain juga mempunyai hak, antara lain hak lintas damai di laut teritorial dan khusus di perairan kepulauan ada hak lintas alur laut kepulauan. Untuk itu, ada beberapa pasal yang menjadi landasan pembahasan :

1) Pasal 2 Ayat (1) dan (2). "Kedaulatan suatu negara pantai, selain wilayah daratan dan perairan pedalamannya dan dalam hal suatu Negara kepulauan, perairan kepulauannya, meliputi jalur laut yang berbatasan dengannya yang dinamakan laut territorial. Kedaulatan ini meliputi ruang udara di atas laut teritorial serta dasar laut dan tanah dibawahnya."
2) Pasal 39 ayat (3). "Pesawat udara dalam lintas transit harus :

a) Mentaati peraturan udara yang ditetapkan oleh Organisasi Penerbangan Sipil Internasional (ICAO), berlaku bagi pesawat udara sipil, dan pesawat udara pemerintah, serta setiap waktu beroperasi dengan mengindahkan keselamatan penerbangan sebagaimana mestinya.

b) Setiap waktu memonitor frekwensi radio yang ditunjuk oleh otorita pengawas lalu lintas udara yang berwenang yang ditetapkan secara internasional atau oleh frekwensi radio darurat internasional yang tepat.

3) Pasal 49. Kedaulatan bagi negara kepulauan meliputi ruang udara di atas perairan kepulauan, juga dasar laut dan tanah di bawahnya dan sumber kekayaan yang terkandung di dalamnya. Kedaulatan ini dilaksanakan sesuai dengan ketentuan sebagai negara kepulauan. Lintas alur laut kepulauan yang ditetapkan dalam suatu negara kepulauan, bagaimanapun tidak boleh mempengaruhi status perairan kepulauan termasuk alur laut atau pelaksanaan kedaulatan oleh negara kepulauan atas perairan dan ruang udara, dasar laut dan tanah dibawahnya serta sumber kekayaan yang terkandung di dalamnya.

\section{c. Ketentuan Kedaulatan Negara di Udara.}

Sampai saat ini belum ada kententuan internasional yang mengatur sengketa bersenjata di ruang udara. Tindakan 
negara-negara dalam hal sengketa udara bertitik tolak kepada Konvensi Chicago 1944 dan berlandaskan kepada prinsip-prinsip kedaulatan negara di udara sesuai dengan undang-undang masing - masing.

Ruang udara kedaulatan mempunyai batas vertikal mulai bumi sampai suatu ketinggian tertentu sesuai kesepakatan bersama secara internasional. Kemampuan Angkatan Udara suatu negara diperlukan untuk mendukung penegakkan kedaulatan negara, sehingga diperhitungkan oleh negaranegara lain. Tanpa Angkatan Udara yang kuat batas kedaulatan negara akan dianggap enteng oleh negara-negara internasional karena batas ketinggian hanya berdasarkan kekuatan dan kemampuan yang dapat ditunjukkan.

1) Teori Tentang Penafsiran Luas Ruang Udara Secara Logika Yuridis.

Teori ini menjelaskan bahwa, "ruang udara "airspace" menurut pengertian Konvensi Chicago adalah jalur ruang udara di atmosfir yang berisikan cukup udara dimana pesawat udara dapat bergerak karena reaksi udara kepadanya sehingga mendapat gaya angkat ("lift"), jarak ketinggian kedaulatan negara di atmosfir kemudian akan ditentukan oleh kesanggupan pesawat udara mencapai ketinggian tertentu ("Ceilling")."

\section{2) Teori Penguasaan Cooper (Cooper's Control Theory).}

Cooper memberikan pengertian kedaulatan negara di ruang udara yaitu ditentukan oleh kemampuan negara-negara yang bersangkutan untuk menguasai udara yang ada di atas wilayahnya. Selanjutnya dari segi hukum dijelaskan bahwa ruang udara ialah bagian atmosfir bumi yang tertentu dimana terdapat cukup gas udara ("gaseous air") untuk memungkinkan penerbangan dengan pesawat udara. ${ }^{6}$

Beberapa pendekatan yang digunakan dalam menentukan batas ketinggian kedaulatan negara antara lain:

1). Batas kedaulatan negara atas dasar lapisan-lapisan atmosfir (atmosfer layers) dan batas yang dianggap paling tepat adalah $80 \mathrm{~km}$.

2). Batas kemampuan terbang pesawat udara yang pada saat ini mencapai ketinggian sekitar 60-80 km.

3). Perigee terendah dari orbit satelit yaitu pada ketinggian antara $80-120 \mathrm{~km}$ ke atas permukaan bumi sehingga disarankan batas terendah antariksa ideal adalah pada ketinggian $100 \mathrm{~km}$.

4). Garis Von Karman yang menganjurkan batas antariksa ditetapkan pada ketinggian $100 \mathrm{~km}$.

5). Teori Penguasaan Efektif (Effective Control) yang menekankan pada kemampuan negara untuk melakukan pengawasan efektif terhadap zona udara di atas wilayah teritorial suatu negara (teritorial space). Zona tersebut kemungkinan diperluas dengan suatu "contigous zone" untuk kepentingan 
pertahanan. Selanjutnya diatas

zona tersebut berlaku kebebasan yang lengkap bagi semua bentuk penerbangan.

6). Teori yang mendasarkan pada sifat-sifat fisika tertentu, state of matter regime, teori medan magnet, rejim medan magnet elektromagnetik, rejim geometris / geografis, rejim biologi / lingkungan, rejim teknologi dan lain-lain.

\section{d. Beberapa Ketentuan tentang Penerbangan.}

Landasan pelaksanaan penerbangan di wilayah udara Indonesia antara lain:

1) Negara Republik Indonesia berdaulat penuh dan utuh atas wilayah udara Republik Indonesia.

2) Dalam rangka penyelenggaraan kedaulatan negara atas wilayah udara Republik Indonesia, pemerintah melaksanakan wewenang dan tanggung jawab pengaturan ruang udara untuk kepentingan pertahanan dan keamanan negara, penerbangan dan ekonomi nasional.

3) Penggunaan pesawat udara sipil asing dari dan ke atau melalui wilayah Republik Indonesia, hanya dapat dilakukan berdasarkan perjanjian bilateral atau perjanjian multilateral atau izin khusus pemerintah. Sedangkan dalam penggunaan pesawat udara negara asing dari dan ke atau melalui wilayah Republik Indonesia hanya dapat dilakukan berdasarkan izin khusus Pemerintah.

4) Dilarang menerbangkan pesawat udara yang dapat membahayakan keselamatan pesawat udara, penumpang dan barang dan/atau penduduk atau mengganggu keamanan dan ketertiban umum atau merugikan harta benda milik orang lain, termasuk terbang di luar jalur yang ditentukan.

5) Pertahanan negara bertujuan untuk menjaga dan melindungi kedaulatan negara, keutuhan wilayah Negara Kesatuan Republik Indonesia dan keselamatan segenap bangsa dari segala bentuk ancaman.

6) TNI bertugas melaksanakan kebijakan pertahanan negara untuk melaksanakan Operasi Militer Selain Perang dan salah satu pengertian operasi militer selain perang dalam penjelasan undang-undang ini adalah berupa pengamanan pelayaran atau penerbangan.

7) Angkatan Udara bertugas : menegakkan hukum dan menjaga keamanan di wilayah udara yurisdiksi nasional sesuai dengan ketentuan hukum nasional dan hukum internasional yang telah diratifikasi. Menegakkan hukum dan menjaga keamanan udara adalah segala usaha, pekerjaan dan kegiatan 
untuk menjamin terciptanya kondisi wilayah udara yang aman serta bebas dari ancaman kekerasan, ancaman navigasi serta pelanggaran hukum di wilayah udara yurisdiksi nasional.

\section{PERMASALAHAN RUANG UDARA DI ATAS ALKI}

Secara umum seluruh ruang udara telah diatur oleh Konvensi Chicago melalui organisasi ICAO antara lain menetapkan 42 jalur diatas wilayah kedaulatan udara Indonesia. Di samping itu, UNCLOS 1982 juga menetapkan penggunaan ruang udara diatas ALKI antara lain "semua kapal dan pesawat udara menikmati hak alur laut kepulauan". Dari kedua aturan ini terjadi berbagai interprestasi seolah-olah pengaturan wilayah ruang udara diatur oleh dua aturan yang berbeda dan ada kemungkinan tidak sinkron. Dengan adanya perbedaan tersebut, kemungkinan akan terjadi permasalahan dalam pelaksanaan pengaturan ruang udara di atas ALKI dan dapat mengganggu keselamatan penerbangan.

\section{a. Pelayanan Rute Udara.}

Dalam Pasal 28 Konvensi Chicago dijelaskan bahwa setiap negara harus menyediakan bandar udara, pelayanan radio, pelayanan meteorologi dan fasilitas navigasi udara untuk dapat melayani pelaksanaan navigasi udara internasional. Salah satu fasilitas navigasi udara tersebut adalah tersedianya rute udara.

Pengertian rute udara yang didefinisikan dalam Air Traffic Services atau Air Traffic Services Route (ATS Route) yaitu, "A specified route designed for channelling the follow of traffic as necessary for the provision of air traffic services". Istilah ATS Route dapat berupa airway, advisory route, ${ }^{7}$ controlled or uncontrolled route, arrival or departure route dan lain sebagainya. ATS Route tersebut ditandai dengan arah ke atau dari titik tertentu (waypoints), jarak antara titik-titik, tempat atau titik dimana harus lapor posisi dan ketinggian terendah yang diperbolehkan pada arah tersebut. Secara khusus bagaimana menetapkan ATS Route ditentukan oleh Principles Governing The Identification of RNP (Required Navigation Performance) Types and The Identification of STS Route Other Than Standard Departure and Arrival Routes.

Tujuannya agar pilot dan petugas lalu lintas udara memungkinkan melakukan otomatisasi dalam pengoperasian pesawat udara yang berhubungan dengan pengaturan lalu lintas. Untuk itu salah satu persyaratan sebelum penerbangan, penerbang harus mencantumkan rute yang dipilih yang terdapat di dalam en-route chart (peta udara yang memuat rute-rute udara yang telah ditetapkan).

Beberapa Rules of The Air atau ketentuan-ketentuan di udara sebagai berikut:

1) Setiap negara harus meyakini bahwa dimanapun pesawat itu

Di dalam Annex ini dijelaskan juga bahwa Airway adalah sebuah kawasan atau bagian tertentu darinya yang diperuntukkan sebagai lorong yang diperlengkapi dengan alat bantu navigasi radio, (seperti Automatic Direction Finder /ADF-Penulis), (Annex 2 Chapter 1 Definitions, halaman 2). Advisory Route adalah rute yang dirancang yang memungkinkan diberikannya saran bagi pelaksanaan lalu lintas udara, (Annex 11 Chapter 1 Definitions, halaman 1-1) 
berada akan mematuhi peraturan dan ketentuan - ketentuan yang berhubungan dengan penerbangan yang berlaku.

2) Setiap negara harus mempertahankan peraturannya yang diakui dan umum secara berkelanjutan, serta diberlakukan dari waktu ke waktu berdasarkan Konvensi ini.

3) Ketentuan yang berlaku bagi penerbangan di atas laut bebas adalah seperti yang tercantum di dalam Konvensi ini.

4) Setiap negara harus memungkinkan penuntutan kepada setiap orang yang melanggar ketentuan-ketentuan yang berlaku.

Secara khusus diatur tentang Flight Plan. Sebelum penerbangan, maksud penerbangan tersebut harus disampaikan kepada Air Traffic Services Units atau unit pelayanan lalu lintas udara dalam bentuk sebuah Flight Plan.

Isi dari rencana penerbangan, antara lain identifikasi pesawat, jenis penerbangan yang dipilih dapat berupa terbang instrumen atau visual (terbang dengan menggunakan tandatanda darat sebagai petunjuk) dan tipe dari penerbangan sipil atau militer, nomor dan tipe pesawat, rute yang dipilih, tujuan pendaratan dan lainlain sebagainya.

Rencana penerbangan ini harus disampaikan 1 (satu) jam sebelum penerbangan atau bisa disampaikan pada saat terbang dengan menggunakan radio komunikasi paling tidak 10 (sepuluh) menit sebelum memasuki titik dimana ada area pengaturan atau titik dimana melewati rute udara atau rute-rute yang telah ditetapkan. Ada 5 (lima) bentuk penerbangan yang mengharuskan menyerahkan Flight Plan yaitu:

1) Setiap penerbangan yang diberikan pelayanan pengaturan lalu lintas udara.

2) Setiap penerbangan dengan Instrumen Flight Rules (terbang dengan menggunakan instrumen sebagai pedoman) di dalam suatu wilayah udara yang telah ditetapkan seperti menggunakan rute-rute yang telah ada.

3) Setiap penerbangan di dalam atau menuju wilayah yang telah ditetapkan atau sepanjang rute yang telah ditetapkan. Hal ini diperlukan oleh otoritas Air Traffic Service (ATS) yang berwenang untuk memudahkan pelayanan informasi penerbangan, kewaspadaan dan layanan pencarian dan pertolongan.

4) Setiap penerbangan di dalam atau menuju wilayah yang telah ditetapkan atau sepanjang rute yang telah ditetapkan. Hal ini diperlukan oleh otoritas ATS yang berwenang untuk memudahkan koordinasi dengan unit Angkatan Udara yang berwenang atau unit pelayanan lalu lintas udara negara tetangga dalam rangka menghindari kemungkinan intersepsi untuk tujuan identifikasi.

5) Setiap penerbangan yang melewati perbatasan internasional. 
b. Rute Udara Dalam UNCLOS 1982. Beberapa pasal UNCLOS 1982 tentang rute udara adalah sebagai berikut :

1) Suatu Negara kepulauan dapat menentukan alur laut dan rute penerbangan di atasnya, yang cocok digunakan untuk lintas kapal dan pesawat udara asing yang terus menerus dan langsung serta secepat mungkin melalui atau di atas perairan kepulauannya dan laut teritorial yang berdampingan dengannya.

2) Semua kapal dan pesawat udara menikmati hak lintas Alur laut kepulauan dalam Alur Laut dan rute penerbangan.

3) Lintas alur laut kepulauan berarti pelaksanaan hak pelayaran dan penerbangan sesuai dengan ketentuan-ketentuan dalam cara normal, semata-mata untuk melakukan transit yang terus menerus, langsung dan secepat mungkin serta tidak terhalang antara satu bagian laut lepas atau zona ekonomi eksklusif lainnya.

4) Alur laut dan rute udara tersebut harus melintasi perairan kepulauan dan laut teritorial yang berdampingan dan mencakup semua rute lintas normal yang digunakan sebagai rute atau alur untuk pelayaran internasional atau penerbangan melalui atau melintasi perairan kepulauan.

5) Mentaati peraturan udara yang ditetapkan oleh Organisasi Penerbangan Sipil Internasional (ICAO) dan setiap waktu beroperasi dengan mengindahkan keselamatan penerbangan sebagaimana mestinya.
6) Setiap waktu memonitor frekwensi radio yang ditunjuk oleh otorita pengawas lalu lintas udara yang berwenang yang ditetapkan secara internasional atau oleh frekwensi radio darurat internasional.

\section{c. Kedaulatan Negara Di Udara.}

Pada awal pembahasan masalah hukum udara, dimulai dengan membicarakan prinsip kedaulatan negara di udara yang berkembang sebelum Perang Dunia I. Hal ini ditandai dengan persengketaan pada saat terjadinya perang antara Perancis dan Jerman tahun $1870-1871$.

Pada saat itu, Perancis telah menggunakan balon-balon untuk menyelidiki kedudukan tentara Jerman. Kemudian, saat Perang Dunia I berlangsung telah menjadi bukti bahwa betapa pentingnya status hukum dari wilayah udara dari sebuah negara dan prinsip bahwa sebuah negara harus mempunyai kedaulatan penuh atas wilayah udara di atas tanah dan laut teritorialnya. ${ }^{8}$

Oleh karena itu, untuk pertama kalinya diselenggarakan konferensi pada tahun 1919 di Paris dengan nama Convention Relating To The Regulation Of Aerial Navigation dan salah satu prinsip yang banyak berkembang saat itu dan diusulkan oleh banyak negara diadopsi sebagai dasar yaitu tercantum didalam Pasal 1 bahwa setiap negara mempunyai kedaulatan yang utuh dan eksklusif di atas udara wilayah teritorialnya.
8 J.L. Brierly, The Law of Nations, (New York and Oxford: Oxford University Press, 1963), halaman 218. 
Kebutuhan akan kedaulatan negara di udara dengan menetapkan suatu rute udara, muncul jauh sebelum Perang Dunia I atau ditemukannya pesawat terbang pada tahun 1903. Wenceslas J. Wagner membagi menjadi 3 bagian dari teori-teori yang berhubungan dengan status ruang udara yaitu Pertama, the extremes theories yang terdiri dari unlimited freedom dan sovereignty of the state over the air space above their territory. Kedua, Intermediate Theories yang terdiri dari limited freedom of the air dan limited soveregnty. Terakhir adalah the second freedom of the air before 1919. ${ }^{9}$

Dengan diakuinya Indonesia sebagai negara kepulauan (Archipelago State) berdasarkan UNCLOS 1982, konsekuensinya Indonesia harus menyediakan fasilitas Alur Laut Kepulauan Indonesia (ALKI) yang memotong laut teritorial dari batas ZEE lainnya.

Ketentuan tersebut diantaranya juga telah memberikan ijin terbang bebas bagi setiap pesawat asing di ruang udara di atas ALKI yang berarti telah menabrak ketentuan Konvensi Chicago 1944 yang mengatur "hak kewenangan yang utuh, penuh dan menyeluruh" atas ruang udara suatu negara. Perbedaan pandangan terutama antar Negara kepulauan sendiri yang sebelumnya muncul, sudah mulai menemukan persepsi yang sama dan terhadap kepentingan negara-negara maju terutama negara maritim juga sudah dapat diakomodasikan melalui berbagai pertemuan informal seperti dengan Amerika Serikat dan Uni Sovyet.

\footnotetext{
${ }^{9}$ Wenceslas J. Wagner, Internasional Air

Transportation As Affected By State Sovereignty,

(Bruylant.Bruxelles: Establissements Emile Bruylant 67, rue de la regence, 1970) halaman 13-31.
}

Untuk itu Indonesia telah mengusulkan beberapa amandemen terhadap pasal tentang Negara kepulauan. Seperti prinsip yang menetapkan bahwa lintas Alur laut kepulauan adalah rights of navigation and overflight bukan fredoom of navigation. Namun menyangkut rejim lintas udara dan hak-hak Negara kepulauan dalam membuat peraturan perundang-undangan tentang lintas alur laut dan kewajiban bagi kapal laut dan pesawat udara, masih terdapat permasalahan, antara lain :

1) Amerika Serikat hanya bersedia mengakui konsepsi negara kepulauan jika negara kepulauan mengakui hak lintas penerbangan pesawat udara asing, tanpa membedakan apakah pesawat udara itu sipil atau Negara.

2) Amerika Serikat khawatir hal itu akan mendorong negara-negara lain untuk juga menuntut pembedaan rejim tersebut di atas laut wilayah.

3) Dalam praktek, lintas penerbangan pesawat udara sipil di atas Alur Laut terutama scheduled internasional air service akan sulit dilaksanakan karena negara kepulauan tidak berkewajiban untuk memberikan bantuan navigasi hingga mereka praktis harus terbang diluar Alur Laut dan mengikuti rute ICAO dan tunduk pada ketentuan ICAO.

\section{d. Permasalahan Penafsiran.}

Pasal - pasal dalam UNCLOS 82 sangat komprehensif sehingga banyak hal yang akhirnya menimbulkan perbedaan penafsiran. Perbedaan ini menurut Martin Tsamenyi banyak disebabkan oleh rumusan dari pasal tersebut yang kurang lengkap dan jelas sehingga ditafsirkan berbeda oleh setiap 
negara berdasarkan kepentingan nasionalnya,${ }^{10}$.

Beberapa permasalahan tersebut yang juga berimplikasi pada penggunaan rute udara di atas ALKI sebagai berikut:

1) Pada ayat (1) kalimat “...suatu Negara kepulauan dapat menentukan alur laut dan rute penerbangan ....", dan pada ayat (4) menyatakan bahwa "alur laut dan rute udara tersebut harus melintasi perairan kepulauan dan laut teritorial yang berdampingan dan mencakup semua rute lintas normal yang digunakan sebagai rute atau alur untuk pelayaran internasional atau penerbangan....". Kalimat ini dapat ditafsirkan bahwa dengan kata "dapat" berarti ini bukan suatu keharusan, dan lebih merupakan suatu pilihan bagi negara kepulauan untuk menyediakan alur yang cocok. Indonesia sendiri melalui PP No 37/2002 menafsirkannya dengan hanya menentukan 3 (tiga) alur laut kepulauan, sehingga menimbulkan tuntutan bagi negara lain terutama Amerika dan Australia yang sangat berkepentingan dengan alur yang mencakup semua rute normal yang dilewati oleh navigasi internasional. Hal inilah yang menjadi dasar Amerika dan Australia tetap menuntut adanya ALKI selain rute yang ada sekarang ini.

2) Pada ayat (2) Kalimat "Semua kapal dan pesawat udara dapat menikmati hak lintas...", ini menunjukkan bahwa pesawat sipil pun dapat melewati rute tersebut padahal

${ }^{10}$ Martin Tsamenyi, Kuliah Law of The Sea, Sekolah Staf dan Komando Angkatan Laut, Angkatan 43, 25 dan 26 April 2005. menurut ketentuan Konvensi ICAO bahwa pesawat sipil internasional sepenuhnya tunduk kepada ketentuan penerbangan sipil. Dengan demikian yang dimaksud dengan ayat tersebut adalah rute untuk penerbangan pesawat negara sehingga tidak bertentangan dengan ketentuan ICAO, karena hanya ICAO yang berwenang menetapkan rute udara termasuk di atas ALKI. Sedangkan Australia berpandangan lain bahwa pesawat yang dimaksud dalam ayat ini adalah yang berhubungan dengan pesawat yang ada di kapal ${ }^{11}$, termasuk pesawat sipil.

3) Pada ayat (3) kalimat "...hak pelayaran dan penerbangan sesuai dengan ketentuan-ketentuan Konvensi ini dalam cara normal semata-mata...", "normal semata-mata" juga dapat dipersepsikan berbeda, Amerika pada kasus Bawean menganggap bahwa menerbangkan pesawat F-18 Hornet dari kapal induk dengan melaksanakan manuver merupakan kegiatan normal semata-mata karena merupakan bagian dari pergerakan kapal induk untuk pengamanan pelayaran kapal induk. Dalam kejadian ini pesawat tersebut terbang tidak saja terbang di atas ALKI bahkan di atas Pulau Bawean berdasarkan pemantauan Radar TNI AU dan Radar Sipil dengan berbagai manuver pada ketinggian bervariasi tanpa komunikasi dengan Air Traffic Controller serta tidak ada pemberitahuan ke pemerintah Indonesia. Sedangkan Indonesia menganggap manuver pesawatpesawat tersebut sudah tidak sesuai 
dengan ketentuan UNCLOS 1982 dan hukum udara sehingga melayangkan protes diplomatik dan meminta Amerika menghargai dan menghormati kedaulatan wilayah Indonesia yang telah dikuatkan oleh Konvensi Hukum Laut Internasional. Dalam praktek pelaksanaan penerbangan karena perbedaan penafsiran tersebut negara-negara lain hanya menggunakan ketentuan UNCLOS 1982, apabila mendukung kepentingannya.

\section{KEBIJAKAN DAN LANGKAH ANTISIPASI}

Indonesia sebagai negara kepulauan (Archipelago State) berdasarkan UNCLOS 1982, mempunyai konsekuensi menyediakan fasilitas Alur Laut Kepulauan Indonesia (ALKI) yang memotong laut teritorial dari batas ZEE ke batas ZEE lainnya. Disisi lain UNCLOS 1982 juga telah memberikan ijin terbang bebas bagi setiap pesawat asing di ruang udara diatas ALKI, padahal Konvensi Chicago 1944 telah mengatur rute ATS diatas ruang udara suatu negara. Pada bagian lain juga diatur bahwa "negara mempunyai kedaulatan yang bersifat lengkap dan ekslusif atas ruang udara diatas wilayahnya". Dengan perbedaan tersebut perlu disusun konsep untuk mendapatkan sinkronisasi ketentuanketentuan tersebut.

a. Apabila diperhatikan definisi ruang udara diatas wilayah, kedaulatan menurut Konvensi Chicago 1944 dan UNCLOS 1982, ada perluasan definisi wilayah, namun perbedaan tersebut tidak prinsip. Artinya seluruh ruang udara diatas wilayah suatu negara yang diakui secara internasional merupakan ruang udara kedaulatan negara yang bersangkutan. Pengertian wilayah menurut Konvensi Chicago hanya daratan dan perairan teritorial yang disesuaikan dengan definisi wilayah pada waktu membuat Konvensi. Dengan perkembangan kesepakatan internasional, sesuai prinsip negara kepulauan, pengertian wilayah disamping daratan dan laut teritorial ditambah dengan zona tambahan, ZEE, Laut Kepulauan (LK) serta perairan kepulauan dan perairan pedalaman (zonasi dalam garis pangkal). Seluruh ruang udara diatas wilayah tersebut diatur sesuai zonasi oleh negara bersangkutan (negara kolong). Walaupun tidak semua ruang udara diatas zonasi sebagai wilayah kedaulatan, paling tidak pengaturan oleh negara kolong.

b. Seluruh wilayah udara Indonesia telah ditetapkan jalur penerbangan (rute ATS), dengan 42 jalur (sesuai kesepakatan ICAO), beberapa diantara jalur tersebut memotong wilayah udara diatas ALKI. Disisi lain UNCLOS 1982 memberikan ketentuan pesawat dapat terbang di ruang udara diatas ALKI yang bukan bagian dari rute ATS. Dengan diperbolehkannya pesawat udara terbang diatas ALKI, kemungkinan akan menabrak rute ATS yang ada karena berpotongan tanpa dilengkapi dengan aturan baku seperti ketentuan ketinggian, titik memberi laporan (repotingi point) dan kewajiban lainnya. Secara normatif apabila diatas ALKI ada jalur penerbangan, mau tidak mau harus ditetapkan sebagai rute ATS, agar sesuai dengan ketentuan ICAO terutama tentang keselamatan penerbangan dan kedaulatan negara kolong. Disamping itu pesawat yang terbang pada rute ATS selain pesawat sipil harus mendapat ijin dari negara kolong. 
c. Agar Indonesia tidak dirugikan, konsep ALKI harus tetap diakui, dan disisi lain keselamatan serta keamanan penerbangan dapat dijamin (sesuai ketentuan ICAO) dan kedaulatan negara dapat ditegakkan, maka kebijakan yang dapat ditempuh Indonesia adalah, mengusulkan dalam sidang IMO dan ICAO sebagai berikut:

1) Pemberlakuan sepenuhnya ketentuan UNCLOS 1982 dan ICAO dengan menambahkan beberapa pengertian.

2) Penetapan ruang udara diatas ALKI, sebagai rute ATS di wilayah udara Indonesia sesuai ketentuan ICAO sehingga rute ATS yang semula 42 menjadi 45 rute ATS.

3) Penambahan pengertian kalimat “ semua kapal dan pesawat udara dapat menikmati hak lintas ......", semua pesawat dapat terbang diatas ALKI, sesuai dengan rute ATS yang telah ditetapkan, khusus pesawat negara harus mendapat izin (ketentuan ICAO) dan pesawat yang melekat di armada kapal dapat terbang dengan jarak dari sumbu ALKI sesuai ketentuan UNCLOS 1982 dan ketinggian sesuai aturan ICAO.

\section{Selanjutnya diperlukan Langkah}

\section{Antisipasi, sebagai berikut:}

a. Mengkoordinasikan dan meningkatkan diplomasi politik agar tiga ALKI termasuk ketentuan ruang udara diatasnya diterima oleh semua negara pihak (contracting state) dengan tetap memperhatikan kepentingn nasional.

b. Meningkatkan kemampuan fasilitas penerbangan dan kekuatan pertahanan udara untuk menegakkan hukum sesuai ketentuan UNCLOS 1982 dan ICAO, antara lain :

1) Mengembangkan kekuatan dan meningkatkan kemampuan deteksi dini berupa radar-radar EW dan radar GCI di wilayah Indonesia Timur.

2) Mengembangkan kekuatan dan kapabilitas K3-I dengan pesawat AEW dan AWACS.

3) Menambah kekuatan pemukul berupa pesawat-pesawat buru sergap, Rudal Hanud dan meriammeriam penangkis serangan udara.

4) Merevisi dan melengkapi peraturan perundang-undangan serta menyusun aturan pelibatan (Rules of Engagement) sesuai perubahan peraturan perundang-undangan tersebut.

5) Mendorong pertumbuhan industri kedirgantaraan di masyarakat untuk mendukung logistik pertahanan.

c. Meningkatkan kerjasama pengawasan baik dalam maupun luar negeri (internasional) terhadap berbagai pelanggaran kedaulatan yang cenderung mengarah pada eskalasi konflik kepentingan dalam pengelolaan ruang udara nasional.

d. Memanfaatkan forum-forum seperti GNB dan Development 8 (D-8) terutama untuk proyek kerjasama di bidang pengembangan teknologi penerbangan.

e. Memperjuangkan dalam pertemuan ICAO dan IMO tentang pengaturan ruang udara diatas ALKI, sebagai berikut :

1) Penerimaan dan pengakuan seluruh negara di dunia melalui otoritas organisasi internasional terhadap ALKI yang telah 
ditetapkan oleh Indonesia, dan telah menampung semua rute normal sesuai ketentuan UNCLOS 1982.

2) Ruang udara diatas ALKI bukan wilayah udara bebas, namun dapat ditetapkan sebagai bagian dari rute ATS sesuai ketentuan ICAO.

3) Menambah pengertian dari kalimat "semua kapal dan pesawat udara dapat menikmati hak lintas ...." dengan :

a) Semua pesawat dapat terbang diatas wilayah udara ALKI sebagai rute ATS sesuai ketentuan ICAO.

b) Setiap pesawat udara militer yang terbang melalui rute ATS, harus mendapat izin dari pemerintah Indonesia.

c) Pesawat yang melekat pada kapal yang melintasi ALKI dapat terbang sesuai ketentuan UNCLOS 1982 dan ketinggian tidak menabrak rute ATS.

\section{PENUTUP}

Sebagai penutup dari tulisan disampaikan beberapa kesimpulan sebagai berikut :

pertama; pengertian wilayah dapat disesuaikan dengan perkembangan ketentuan internasional yaitu mengikuti ketentuan wilayah negara kepulauan, sedangkan ruang udara kedaulatan adalah yang berada diatas wilayah tersebut (Konvensi Chicago),

Kedua; semua pesawat udara dapat terbang diatas ALKI yang telah ditetapkan sebagai jalur ATS, dengan mengikuti aturan keselamatan penerbangan, kedaulatan suatu negara dan ketentuan ICAO serta UNCLOS 1982. Penetapan jalur ATS diatas ALKI diatur sedemikian rupa agar tidak merubah ATS yang ada dan dalam waktu secepat mungkin diajukan ke ICAO. Beberapa saran untuk dipertimbangkan :

a. Pemerintah perlu memprioritaskan pembangunan kekuatan udara baik sipil maupun militer.

b. Meningkatkan loby internasional terutama dalam organisasi ICAO dan IMO, agar kepentingan Indonesia dapat tercapai.

c. Meningkatkan kerjasama dalam penggunaan sarana penerbangan antara sipil militer, termasuk penggunaan radar.

\section{DAFTAR PUSTAKA}

1. Annex 2, "Rule of The Air", Convention on International Civil Aviation of 1944" Ninth Edition-July 1990, ICAO, 1991.

2. Annex 11, "Air Traffic Services", Convention on International Civil Aviation of 1944,Thirteenth Edition July 2001.

3. Brierly, J.L., The Law of Nations, Oxford University Press, New York and Oxford, 1963.

4. Cheng, Bin, The Law of International Air Transport, Stevens \& Sons Limited, London, 1962

5. Convention on Internasional Civil Aviation of 1944

6. Cooper, Cobb, John, Explorations In Aerospace Law, Editor Ivan A. Vlasic, McGill University Press, Montreal, 1968 
7. United Nations Convention On The Law Of The Sea 1982

8. Warner, Robin, Edited by Donald R. Rothwell and Sam Bateman, "Navigational Rights and Freedoms and The New Law of The Sea", Martinus Nijhoff Publisher, London, 2000. 